\title{
STUDI PARAMETER MIKROSKOPIK DAN MAKROSKOPIK ARUS LALU LINTAS AKIBAT PENGARUH "RUMBLE STRIPS" TERHADAP PERILAKU PENGEMUDI DI KAMPUS LIMAU MANIS UNIVERSITAS ANDALAS
}

\author{
Putri Oktafiani Muchlis ${ }^{1}$, Purnawan ${ }^{2}$, dan Hendra Gunawan ${ }^{3}$
}

\begin{abstract}
ABSTRAK
Kecelakaan lalu lintas sebagian besar disebabkan oleh pelanggaran terhadap peraturan keselamatan lalu lintas, hal ini menunjukan bahwa kesalahan manusia secara mandiri bertanggung jawab terhadap hampir $50 \%$ kejadian. Penelitian ini bertujuan untuk mengetahui kecepatan kendaraan ketika melewati rumble strips yang ada di kampus Limau Manis UNAND. Penelitian dilakukan di lima lokasi rumble strips yang ada di kampus Limau Manis UNAND. Pengumpulan data di lapangan yaitu data volume lalu lintas, kecepatan,kepadatan dan time headway. Survei dilakukan di tanggal 14 Juni 2013- 4 juli 2013 pada hari kerja (jam 08.45 WIB sampai jam 17.30 WIB). Pengukuran dilakukan sebelum lokasi Rumble Strips, dilokasi rumble strips, kecepatan kendaraan saat akan meninggalkan lokasi rumble strips, saat meninggalkan lokasi rumble strips. Kecepatan rata-rata kendaraan mengalami penurunan sebayak 10,6\% ketika melewati lokasi rumble strips dibandingkan dengan kecepatan rata-rata kendaraan sebelum melewati lokasi rumble strips. Kerapatan ratarata kendaraan dilokasi rumble strips mengalami pertambahan 10,8\% dibandingkan lokasi sebelum rumble strips. Time headway rata-rata kendaraan mengalami penurunan 14,3\% ketika melewati lokasi rumble strips dibandingkan sebelum melewati lokasi rumble strips. Analisis untuk perbandingan pengujian penurunan kecepatan kendaraan ketika melewati rumble strips dengan menggunakan uji z dan t dengan uji Chi-Square. Hasil analisis pengaruh rumble strips terhadap tingkat kecepatan kendaraan di rumble strips menunjukkan penurunan kecepatan, nilai kerapatan semakin besar ketika melewati rumble strips dibandingkan sebelum atau sesudah rumble strips, time headway ketika melewati rumble strips semakin kecil dibandingkan sebelum melewati rumble strips.
\end{abstract}

Kata kunci : volume lalu lintas, kecepatan, kerapatan, time headway, rumble strips, uji z, uji t dan uji chisquare.

\section{PENDAHULUAN}

Kecelakaan lalu lintas sebagian besar disebabkan oleh pelanggaran terhadap peraturan keselamatan lalu-lintas. Treat, dkk (dalam Widya Graha Asana, 2007) meneliti tentang hal ini dan mengemukakan bahwa factor kesalahan manusia secara mandiri dan bertanggung jawab terhadap hampir 50\% kejadian. Melihat bahwa faktor kesalahan manusia merupakan penyumbang terbesar dalam kecelakaan, dibutuhkan adanya sistem keselamatan yang dapat mengendalikan perilaku manusia sebagai pengguna jalan, agar pelanggaran terhadap peraturan keselamatan lalu lintas berkurang jumlahnya. Selama ini pengendalian terhadap perilaku pengemudi kendaraan dilakukan dengan memberi sanksi legal kepada pelanggar. Efektifitas sanksi legal dibuat dan ditetapkan

\footnotetext{
${ }^{1}$ Mahasiswa Pascasarjana Jurusan Teknik Sipil Fakultas Teknik Universitas Andalas oktafiani.pu3@ gmail.com

${ }^{2}$ Staf Pengajar Jurusan Teknik Sipil Fakultas Teknik Universitas Andalas, purnawan@ft.unand.ac.id

${ }^{3}$ Staf Pengajar Jurusan Teknik Sipil Fakultas Teknik Universitas Andalas hendra@ft.unand.ac.id
} 
karena dipercaya merupakan alat yang dapat menuntun perilaku manusia kearah yang lebih diinginkan. Ada beberapa perangkat rekayasa lalu lintas yang bisa digunakan untuk merubah tingkah laku pengguna kendaraan sehingga pengendara tidak membahayakan kendaraan lain serta aman bagi lingkungan sekitarnya dan dapat mereduksi kecepatan kendaraan bermotor, salah satunya adalah dengan cara melengkapi jalan dengan pita penggaduh (rumble strips).

Kecepatan yang diizinkan pada areal jalan kampus Limau Manis UNAND berkisar antara 25 sampai dengan $30 \mathrm{~km} / \mathrm{jam}$. Berdasarkan observasi di lapangan ternyata pengendara kendaraan bermotor menjalankan kendaraannya melebihi kecepatan izin, walaupun sudah terdapat tanda batas kecepatan. Salah satu alat yang digunakan untuk mereduksi kecepatan di kampus Limau Manis UNAND adalah pita penggaduh (rumble strips). Sehingga perlu diteliti kecepatan real kendaraan ketika melewati rumble strips dan besar perubahan kecepatan lalu lintas akibat rumble strips di kawasan kampus Limau Manis UNAND.

\section{LANDASAN TEORI}

\subsection{Rumble Strips}

Pita penggaduh (rumble strips) adalah penambahan tinggi perkerasan jalan (yang merupakan bagian dari marka jalan). Dibuat dengan menggunakan bahan thermoplastic yang dipasang melintang jalan pada jarak yang berdekatan dan memiliki ketinggian tertentu (biasanya 10-40 mm). Tujuan dibuatnya rumble strips adalah untuk menyadarkan pengemudi sehingga kecepatan kendaraan dapat dikurangi demi meningkatkan keselamatan lalu lintas dengan memberikan efek getaran yang dapat dikendalikan, sehingga diharapkan dapat meningkatkan kewaspadaan pengemudi dan mengurangi angka kecelakaan yang ada (Departemen Perhubungan, 1994).

\subsection{Perilaku Pengemudi}

Karakteristik kecepatan lalu lintas menuju perlintasan diasumsikan sebagai gambaran perilaku hatihati (safety behavior) dari pengemudi (Michael, 1993) Perilaku hati-hati pengemudi yang memasuki perlintasan diukur dari penurunan kecepatan total dan kecepatan di dekat perlintasan. Pengurangan kecepatan total didefinisikan sebagai kecepatan maksimum dikurangi kecepatan minimum di dalam zona pengukuran. Nilai pengurangan kecepatan total yang lebih besar mengindikasi perilaku hati-hati yang lebih tinggi.

\subsection{Parameter Mikroskopik dan Makroskopik}

Parameter lalu lintas adalah suatu ukuran yang digunakan untuk menjadi tolak ukur dari suatu sistem transportasi. Parameter lalu lintas dibagi menjadi dua kategori (Tamin, 2008) yaitu:

a. Parameter makroskopik. Parameter yang mencirikan arus lalu lintas sebagai suatu kesatuan (system) secara keseluruhan, secara makrokopis dibagi menjadi tiga macam :

1) Volume lalu lintas. Volume lalu lintas, dinyatakan dengan notasi (V) adalah jumlah kendaraan yang melewati satu titik tertentu dalam satu ruas jalan dalam satuan waktu tertentu, biasa dinyatakan dalam kend/jam.

2) Kecepatan rata-rata kendaraan

3) Kerapatan kendaraan. Kerapatan (Density) lalu lintas, dinyatakan dengan notasi (D) adalah jumlah kendaraan yang berada dalam satuan panjang. Kerapatan yang tinggi menunjukan jarak antar kendaraan cukup dekat, kerapatan yang rendah berarti jarak antar kendaraan cukup jauh.

b. Parameter mikroskopik. Time headway kendaraan. Menurut Tamin (2008) time headway adalah waktu antara kedatangan satu kendaraan dengan kendaraan berikutnya pada suatu titik tinjau. 
Diukur dengan mencatat waktu antara bemper depan kendaraan pertama melintas titik tinjau dengan bemper depan kendaraan berikutnya (front to front).

\section{METODOLOGI}

Adapun diagram alir yang digunakan untuk studi parameter mikroskopik dan makroskopik arus lalu lintas pada pengaruh rumble strips terhadap perilaku pengemudi di kampus Limau Manis Universitas Andalas adalah Gambar 1 berikut ini:

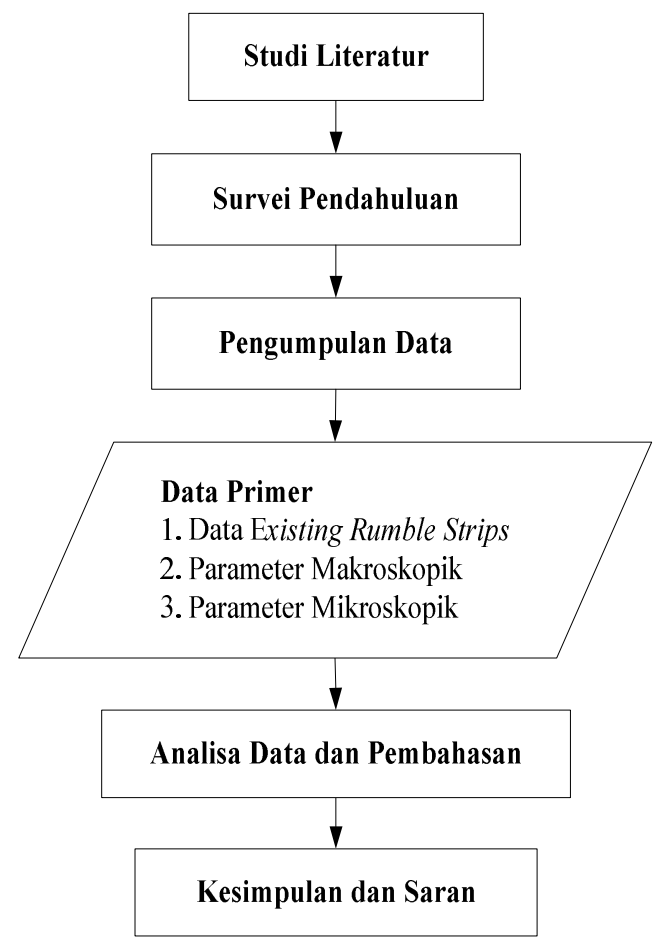

Gambar 1 Diagram Alir Penelitian1

\subsection{Survei Pendahuluan}

Sebelum melakukan penelitian terlebih dahulu dilakukan studi pendahuluan antara lain:

a. Penentuan lokasi penelitian

Ada lima lokasi penempatan rumble strips di kampus Limau Manis UNAND seperti terlihat pada Tabel 1

Tabel 1 Lokasi Penempatan Rumble Strips di Kampus Limau Manis Unand

\begin{tabular}{|l|l|l|l|}
\hline \multirow{2}{*}{ NO } & \multirow{2}{*}{ Lokasi Rumble Strips } & Arah & \\
\cline { 3 - 4 } & & Naik & Turun \\
\hline 1. & Di depan Kopma & FMIPA-FT & FT-FMIPA \\
\hline 2. & Di depan PKM & - & PKM \\
\hline 3. & Di depan Fakultas Ekonomi & PKM-Faterna & Faterna-PKM \\
\hline 4. & Di depan Gedung futsal & Faperta-Kopma & Kopma-Faperta \\
\hline 5. & Di depan Fakultas Peternakan & FE-Faperta & Faperta-FE \\
\hline
\end{tabular}


b. Penentuan titik pengukuran, dapat dilihat pada Gambar 2 berikut:

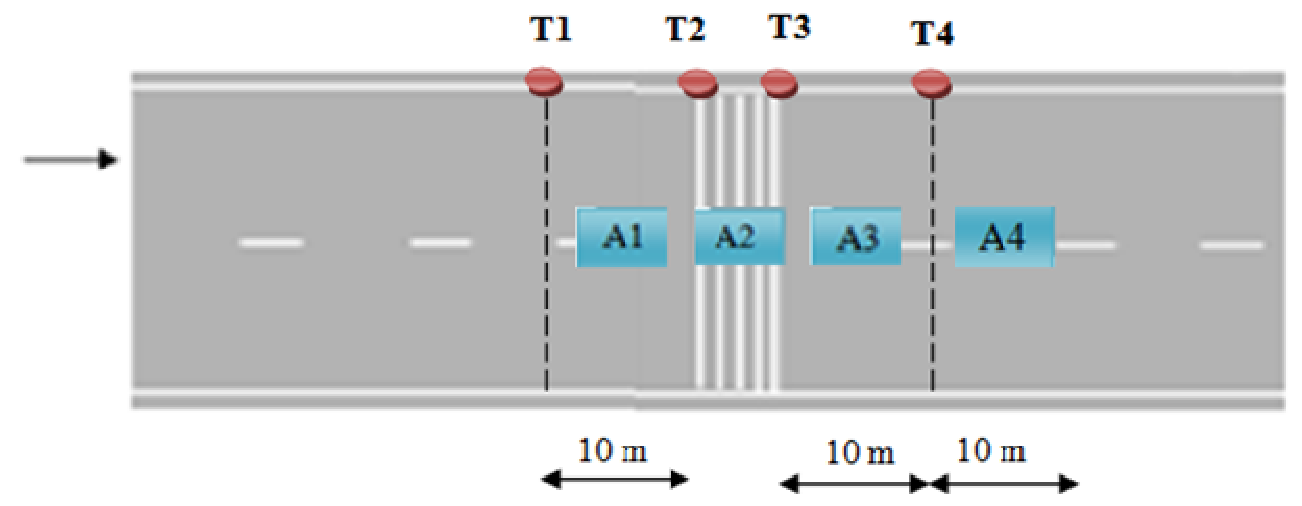

Keterangan titik survai :

A_1 : Area sebelum lokasi rumble strips

A_2 : Area saat menngilas rumble strips

A_3 : Area saat akan meninggalkan rumble strips

A_4 : Area setelah meninggalkan rumble strips

Gambar 2 Sketsa titik lokasi survai

c. Penentuan waktu survai

Survei dilakukan di semester pendek tanggal 14 Juni 2013- 4 juli 2013 pada hari kerja (jam 08.45 WIB sampai jam 17.30 WIB).

\subsection{Pengumpulan Data}

Pengumpulan data primer dilakukan dengan cara survai di lapangan. Data primer dalam penelitian ini antara lain:

a. Data eksisting rumble strips

b. Data parameter makroskopik

1) Survei volume lalu lintas

2) Survei kecepatan kendaraan

3) Kerapatan Lalu Lintas kendaraan

c. Data parameter mikroskopik

1) Time Headway kendaraan

\section{HASIL DAN PEMBAHASAN}

\subsection{Hasil Pengolahan Data Survei}

Hasil pengolahan data survei dibagi atas:

a. Data parameter makroskopik

1) Survei volume lalu lintas

Pembagian jenis kendaraan bermotor yang disurvei dibagi atas lima kategori yaitu: sepeda motor (MC), kendaraan ringan (LV), angkutan umum (angkot), bus (B) dan kendaraan berat (HV). Hasil survei volume kendaraan dapat dilihat pada gambar 3a, b, c, d, dan e sebagai berikut: 
Volume Kendaraan di depan FE arah PKM-Faterna

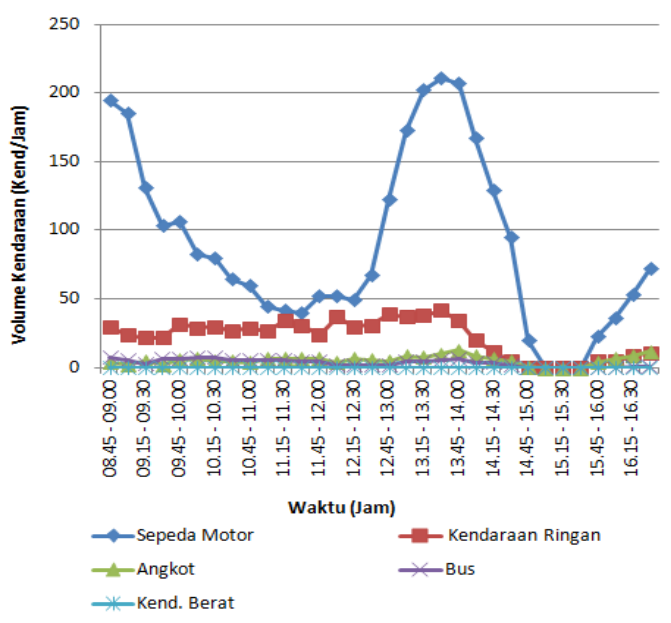

(a)

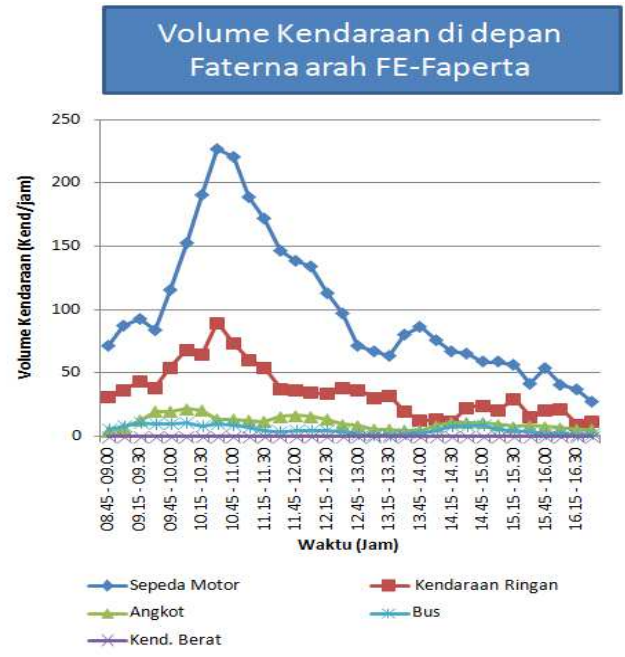

(b)

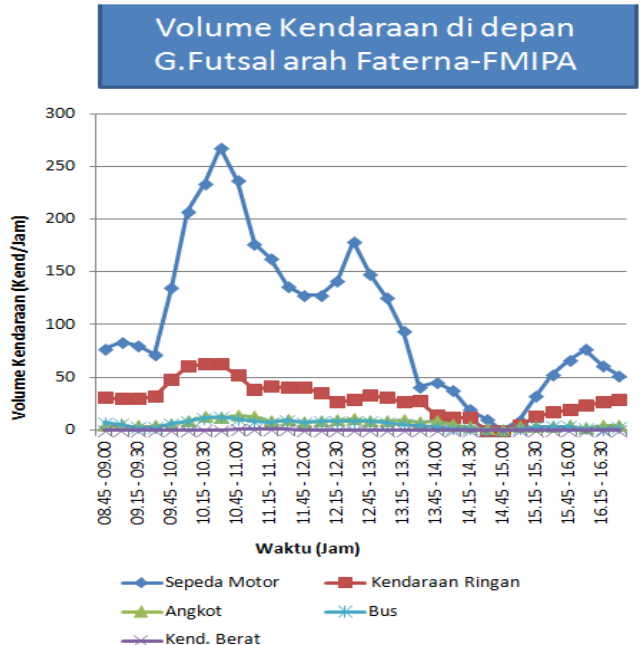

Volume Kendaraan di depan FE arah Faterna-PKM

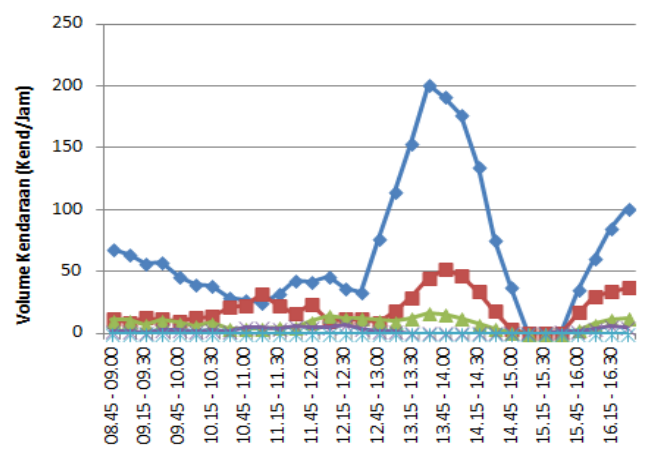

Waktu (Jam)
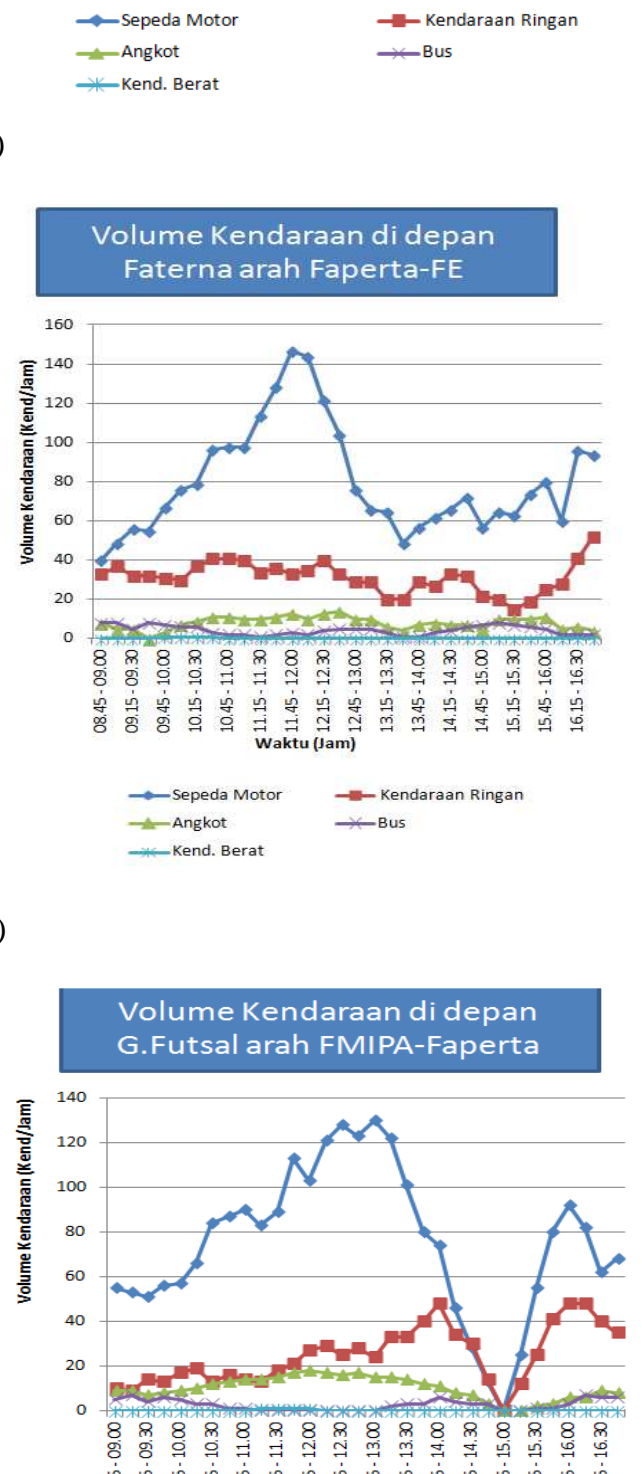

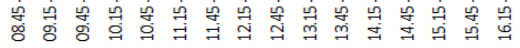
Waktu (Jam)

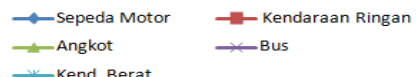

\section{8 | JURNAL REKAYASA SIPIL}


(c)
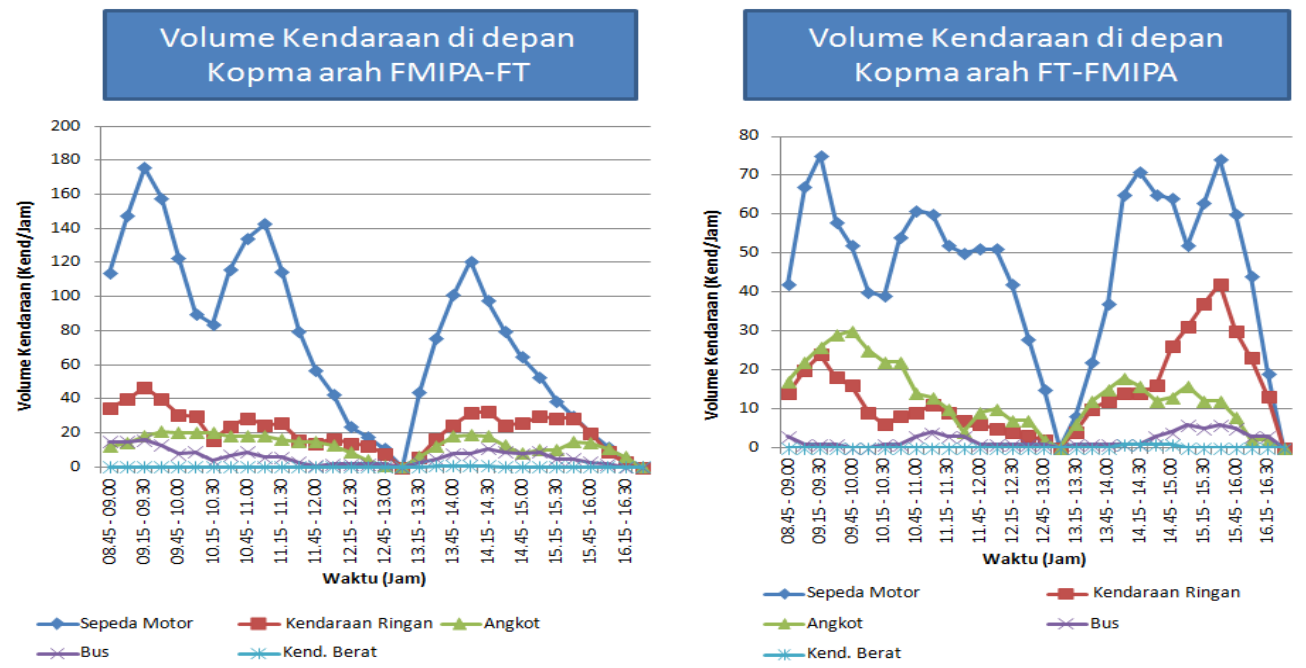

(d)

Volume Kendaraan di depan PKM

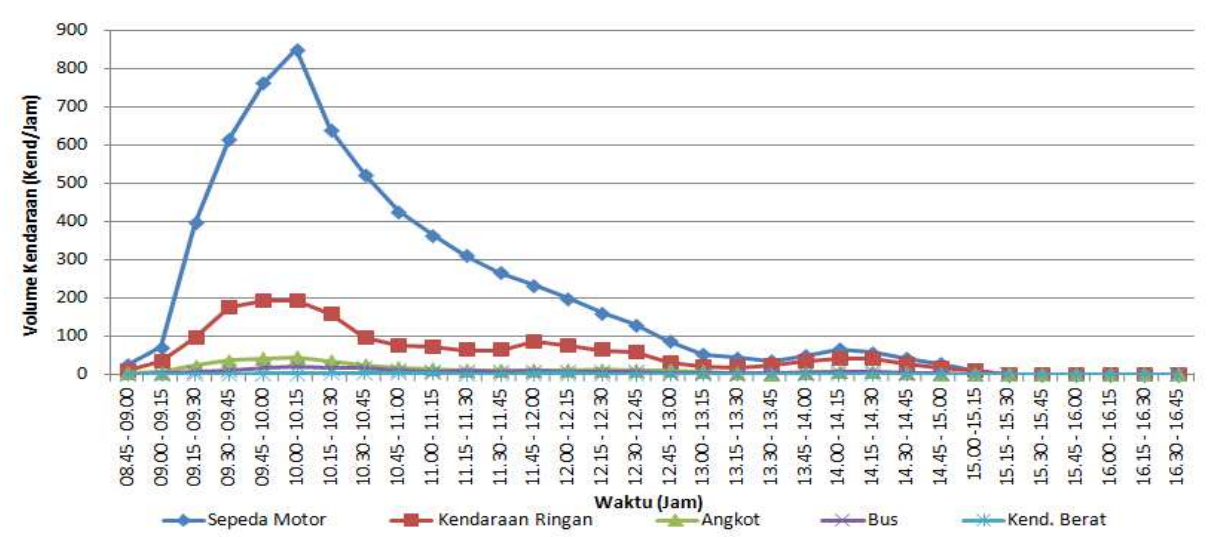

(e)

Gambar 3 Hasil Survei Volume Kendaraan Kampus Limau Manis UNAND

Dari Gambar 3 dapat disimpulkan volume maksimum sepeda motor di lokasi penelitian rumble strips yang paling tinggi adalah dikawasan di depan PKM yaitu 850 kend/jam pada jam 10.00-11.00, untuk volume maksimum kendaraan ringan di lokasi penelitian rumble strips yang paling tinggi adalah dikawasan didepan PKM yaitu 193 kend/jam pada jam 09.45-10.45, untuk volume maksimum angkot di lokasi penelitian rumble strip yang paling tinggi adalah dikawasan PKM yaitu 46 kend/jam pada jam 10.00-11.00, untuk volume maksimum bus di lokasi penelitian rumble strips yang paling tinggi adalah di kawasan didepan PKM yaitu 22 kend/jam, sedangkan volume maksimum kendaraan berat dilokasi penelitian rumble strips yang paling tinggi adalah di kawasan didepan PKM yaitu 5 kend/jam. 
2) Survei kecepatan rata-rata kendaraan

Hasil survei kecepatan rata-rata kendaraan ditunjukkan pada Gambar 4a, b, c, d, e, f, g dan h sebagai berikut:

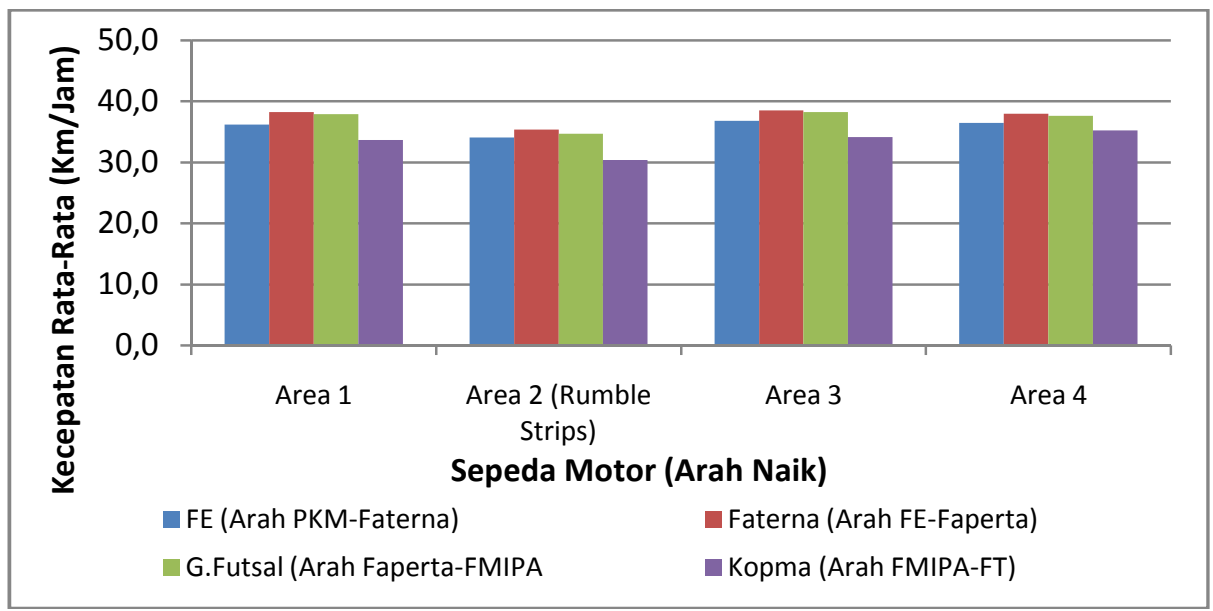

(a)

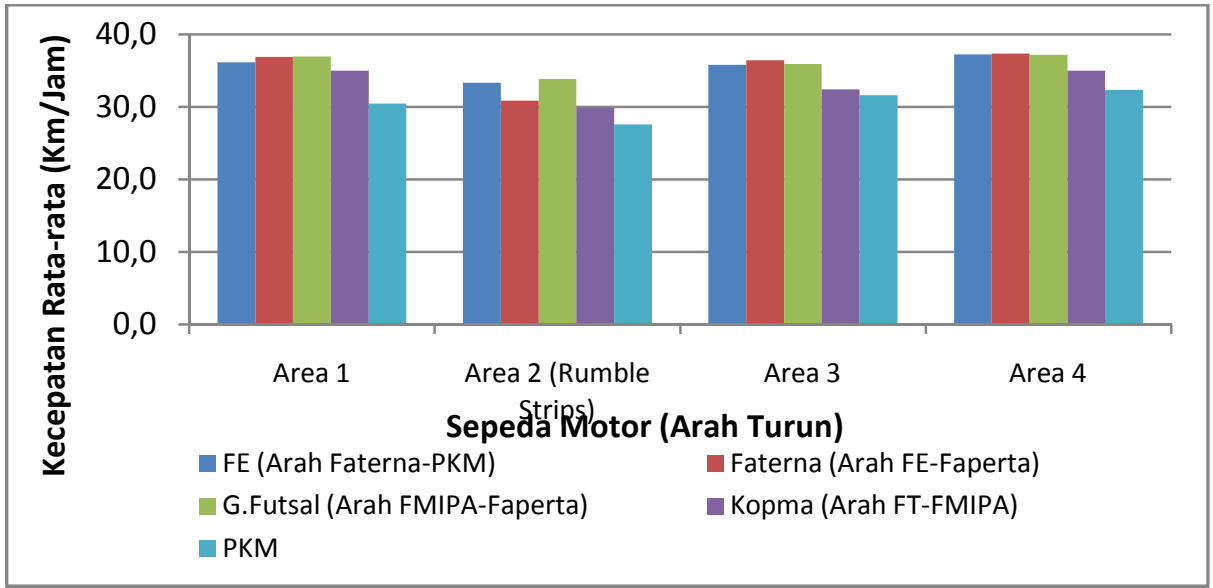

(b)

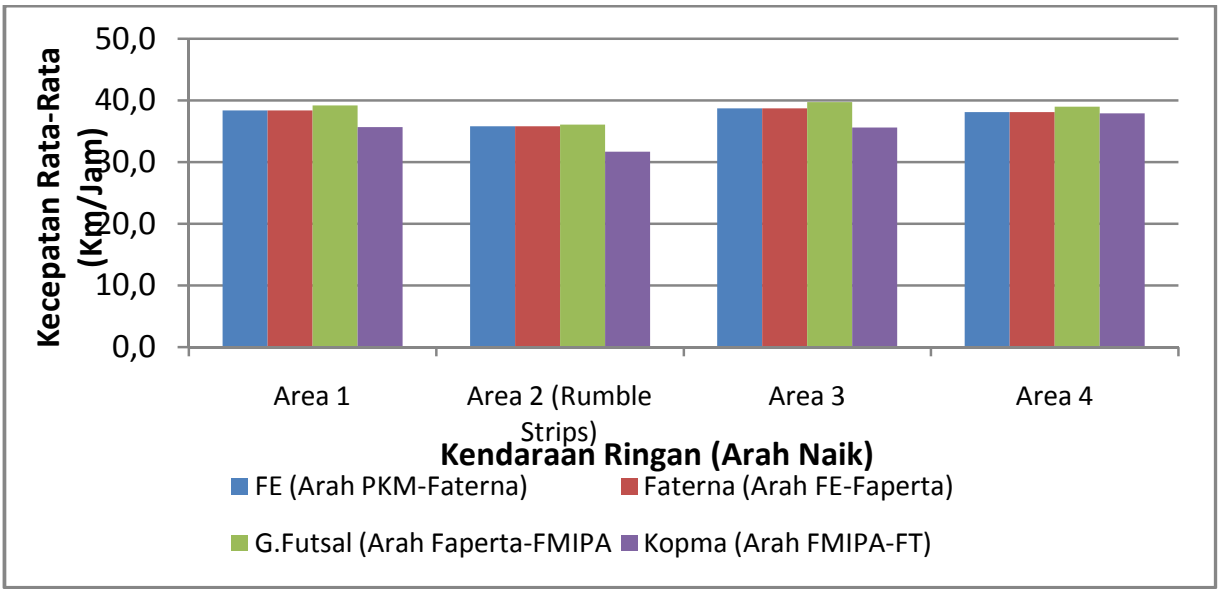

(c) 


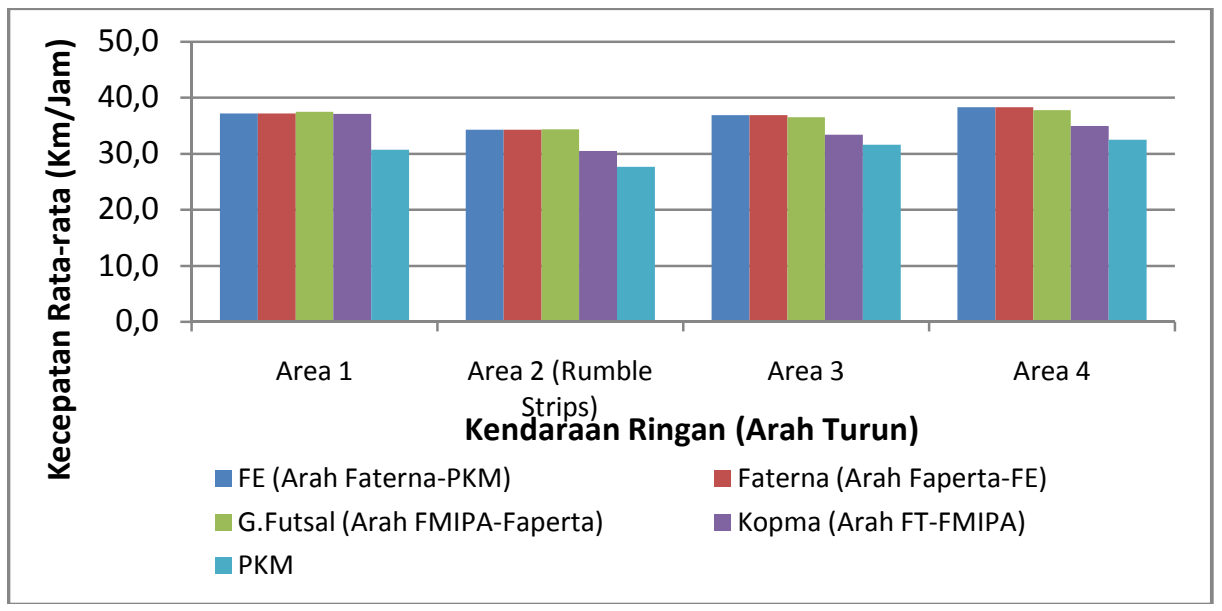

(d)

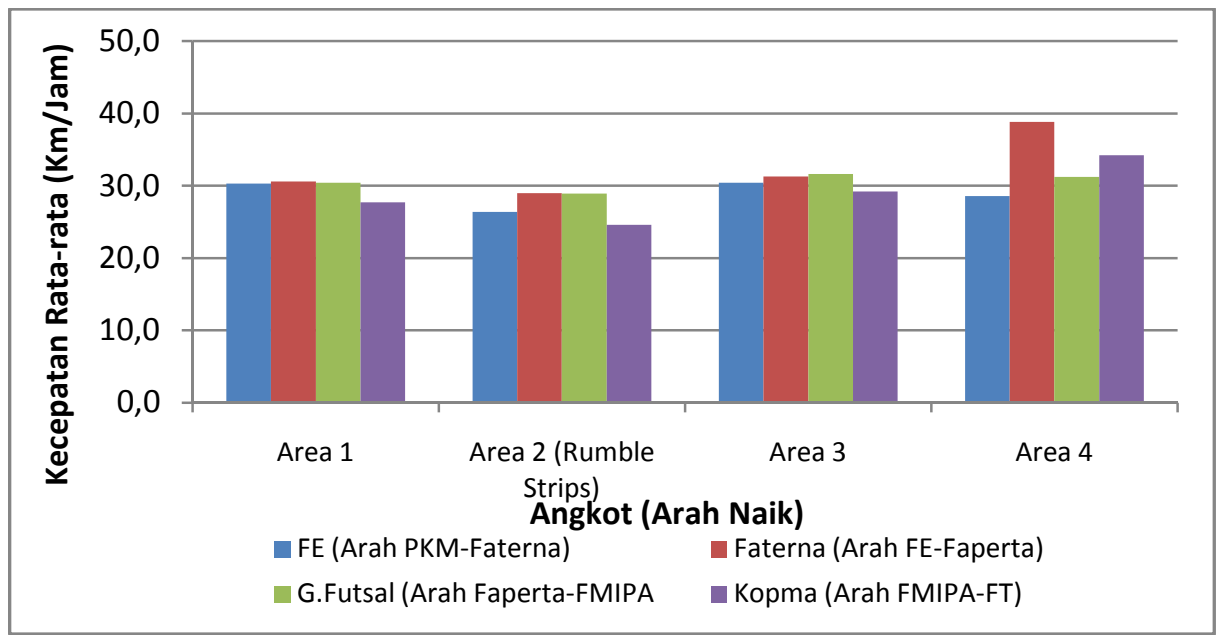

(e)

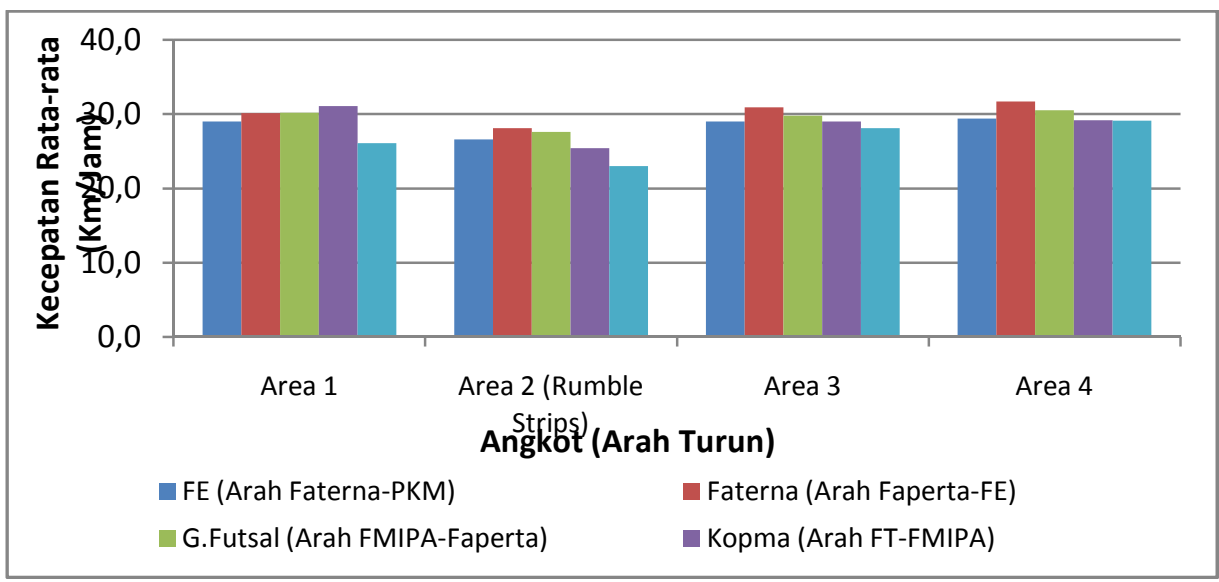

(f) 


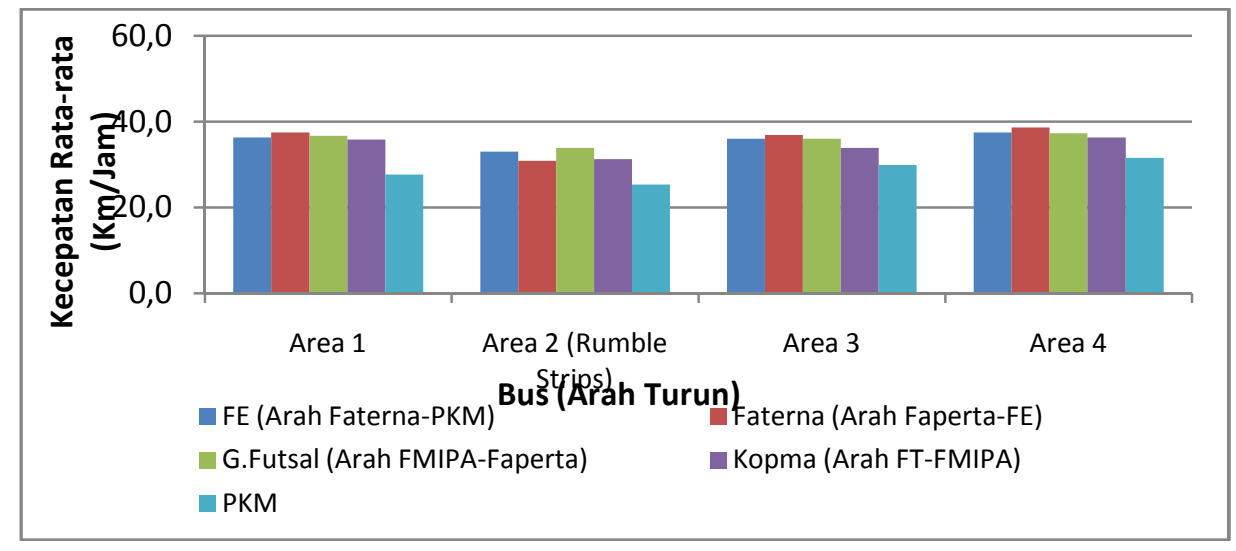

(g)

Gambar 4. Hasil Survei Kecepatan Rata-rata Kendaraan di Kampus Limau Manis UNAND

Dari Gambar 4.dapat disimpulkan bahwa kecepatan rata-rata kendaraan di lokasi penelitian rumble strips mengalami penurunan di area 2 pada rumble strips di bandingkan dengan kecepatan rata-rata kendaraan di area 1 , area 3 dan area 4 . Ini disebabkan karena adanya pengaruh rumble strips terhadap penurunan kecepatan ratarata kendaraan yang melewati lokasi-lokasi tersebut.

3) Kerapatan Lalu Lintas kendaraan

Kerapatan (density) adalah jumlah kendaraan yang berada dalam satuan panjang ( Tamin, 2008) dan kerapatan lalu lintas dapat dilihat pada Gambar 5.

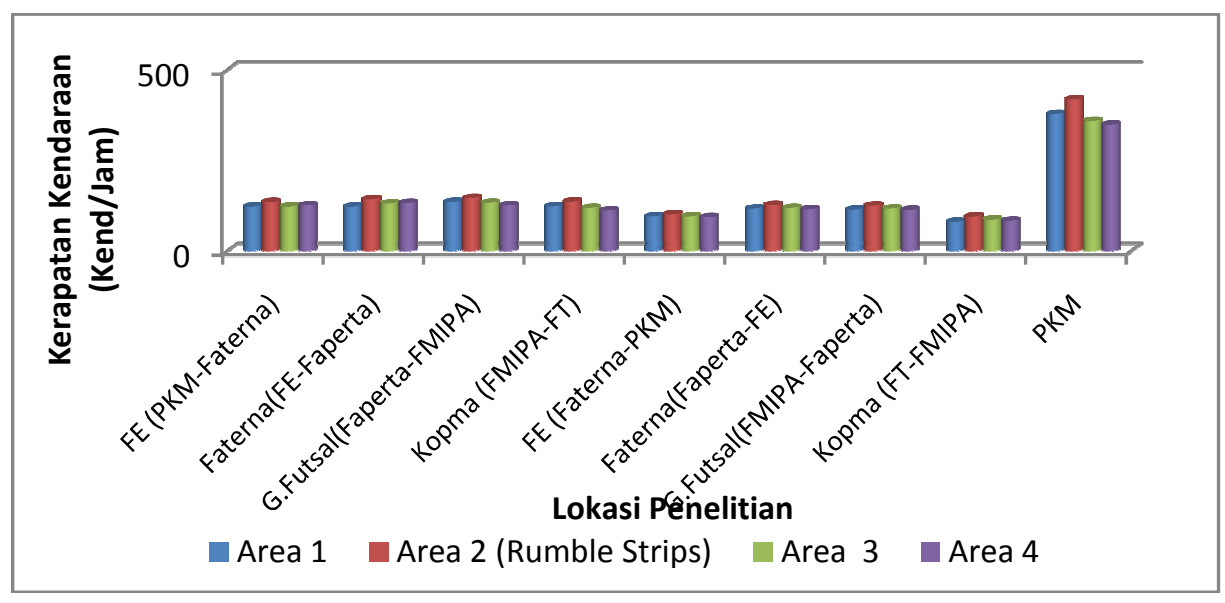

Gambar 5. Hasil Survei Kerapatan Kendaraan di Kampus Limau Manis UNAND

Dari Gambar 5. dapat disimpulkan bahwa kerapatan kendaraan di lokasi penelitian rumble strips mengalami pertambahan kerapatan kendaraan di area 2 pada rumble strips di bandingkan dengan kerapatan kendaraan di area 1, area 3 dan area 4, ini disebabkan adanya pengaruh rumble strips terhadap pertambahan kerapatan kendaraan yang melewati lokasi-lokasi tersebut, karena jarak antar kendaraan ketika melewati rumpatable strip menjadi lebih dekat antara yang satu dengan yang lain sehingga ketika melewati rumble strip nilai kerapatan semakin bertambah. 
c. Data parameter mikroskopik

1) Time Headway kendaraan

Time headway adalah waktu antara kedatangan suatu kendaraan dengan kendaraan berikutnya pada suatu titik tinjau (Tamin, 2008) dan ini dapat dilihat pada Gambar 6.

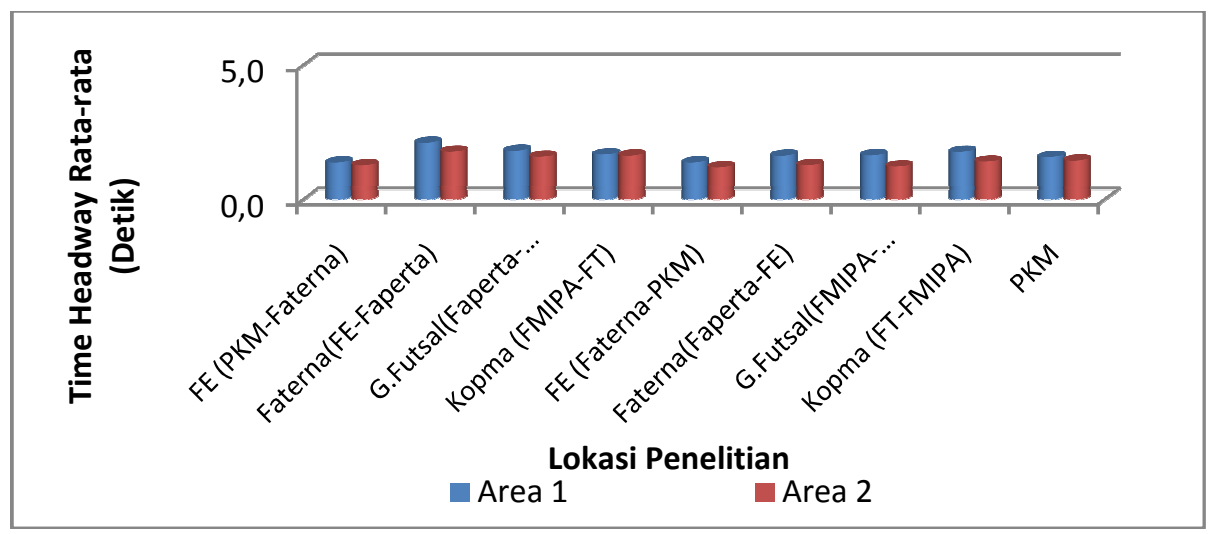

Gambar 6. Hasil Survei Time Headway Kendaraan di Kampus Limau Manis UNAND

Dari Gambar 6 diatas dapat disimpulkan bahwa time headway rata-rata kendaraan di lokasi penelitian rumble strips mengalami penurunan di area 2 pada rumble strips di bandingkan dengan time headway rata-rata kendaraan di area 1 . Ini disebabkan karena adanya pengaruh rumble strips terhadap penurunan time headway rata-rata kendaraan karena waktu antar kendaraan ketika melewati rumble srtrip menjadi lebih dekat sehingga menyebabkan time headway rata-rata kendaraan ketika melewati area 2 (rumble strips) menjadi lebih kecil dibanding area yang lain.

\subsection{Hasil Analisis Statistik}

Hasil Analisis statistik dapat dilihat pada Tabel 2, 3, 4, 5 dan 6 seperti tabel di bawah ini berikut ini:

Tabel 2. Hasil Uji Hipotesis dan Chi-Square perubahan kecepatan di depan FE

\begin{tabular}{|c|c|c|c|c|c|}
\hline \multirow[b]{2}{*}{$\begin{array}{c}\text { Jenis } \\
\text { Kendaraan }\end{array}$} & \multirow[b]{2}{*}{ Lokasi } & \multicolumn{2}{|c|}{ Arah PKM-Faterna } & \multicolumn{2}{|c|}{ Arah Faterna-PKM } \\
\hline & & $\begin{array}{l}\text { Keputusan } \\
\text { Uji z dan t }\end{array}$ & $\begin{array}{c}\text { Keputusan } \\
\text { Uji chi-square }\end{array}$ & $\begin{array}{l}\text { Keputusan } \\
\text { Uji z dan t }\end{array}$ & $\begin{array}{c}\text { Keputusan } \\
\text { Uji chi-square }\end{array}$ \\
\hline $\begin{array}{l}\text { Sepeda } \\
\text { Motor }\end{array}$ & $\begin{array}{l}\text { Area 1-Area 2(Rumble strips) } \\
\text { Area 2(Rumble strips)-Area } 3 \\
\text { Area 3- Area } 4\end{array}$ & $\begin{array}{l}\mathrm{H}_{0} \text { ditolak } \\
\mathrm{H}_{0} \text { ditolak } \\
\mathrm{H}_{0} \text { ditolak } \\
\end{array}$ & $\begin{array}{l}\mathrm{H}_{0} \text { ditolak } \\
\mathrm{H}_{0} \text { ditolak } \\
\mathrm{H}_{0} \text { ditolak } \\
\end{array}$ & $\begin{array}{l}\mathrm{H}_{0} \text { ditolak } \\
\mathrm{H}_{0} \text { ditolak } \\
\mathrm{H}_{0} \text { ditolak }\end{array}$ & $\begin{array}{l}\mathrm{H}_{0} \text { ditolak } \\
\mathrm{H}_{0} \text { ditolak } \\
\mathrm{H}_{0} \text { ditolak } \\
\end{array}$ \\
\hline $\begin{array}{c}\text { Kendaraan } \\
\text { Ringan }\end{array}$ & $\begin{array}{l}\text { Area 1-Area 2(Rumble strips) } \\
\text { Area 2(Rumble strips)-Area } 3 \\
\text { Area 3- Area } 4\end{array}$ & $\begin{array}{l}\mathrm{H}_{0} \text { ditolak } \\
\mathrm{H}_{0} \text { ditolak } \\
\mathrm{H}_{0} \text { ditolak }\end{array}$ & $\begin{array}{l}\mathrm{H}_{0} \text { ditolak } \\
\mathrm{H}_{0} \text { ditolak } \\
\mathrm{H}_{0} \text { ditolak }\end{array}$ & $\begin{array}{l}\mathrm{H}_{0} \text { ditolak } \\
\mathrm{H}_{0} \text { ditolak } \\
\mathrm{H}_{0} \text { ditolak }\end{array}$ & $\begin{array}{l}\mathrm{H}_{0} \text { ditolak } \\
\mathrm{H}_{0} \text { ditolak } \\
\mathrm{H}_{0} \text { diterima }\end{array}$ \\
\hline $\begin{array}{c}\text { Angkutan } \\
\text { Umum }\end{array}$ & $\begin{array}{l}\text { Area 1-Area 2(Rumble strips) } \\
\text { Area 2(Rumble strips)-Area } 3 \\
\text { Area 3- Area } 4\end{array}$ & $\begin{array}{l}\mathrm{H}_{0} \text { ditolak } \\
\mathrm{H}_{0} \text { ditolak } \\
\mathrm{H}_{0} \text { ditolak }\end{array}$ & $\begin{array}{l}\mathrm{H}_{0} \text { ditolak } \\
\mathrm{H}_{0} \text { ditolak } \\
\mathrm{H}_{0} \text { ditolak } \\
\end{array}$ & $\begin{array}{l}\mathrm{H}_{0} \text { ditolak } \\
\mathrm{H}_{0} \text { ditolak } \\
\mathrm{H}_{0} \text { diterima }\end{array}$ & $\begin{array}{c}\mathrm{H}_{0} \text { ditolak } \\
\mathrm{H}_{0} \text { ditolak } \\
\mathrm{H}_{0} \text { diterima }\end{array}$ \\
\hline Bus & $\begin{array}{l}\text { Area 1-Area 2(Rumble strips) } \\
\text { Area 2(Rumble strips)-Area } 3 \\
\text { Area 3- Area } 4\end{array}$ & $\begin{array}{l}\mathrm{H}_{0} \text { ditolak } \\
\mathrm{H}_{0} \text { diterima } \\
\mathrm{H}_{0} \text { diterima }\end{array}$ & $\begin{array}{l}\mathrm{H}_{0} \text { ditolak } \\
\mathrm{H}_{0} \text { ditolak } \\
\mathrm{H}_{0} \text { diterima }\end{array}$ & $\begin{array}{l}\mathrm{H}_{0} \text { ditolak } \\
\mathrm{H}_{0} \text { ditolak } \\
\mathrm{H}_{0} \text { ditolak }\end{array}$ & $\begin{array}{c}\mathrm{H}_{0} \text { ditolak } \\
\mathrm{H}_{0} \text { ditolak } \\
\mathrm{H}_{0} \text { diterima }\end{array}$ \\
\hline
\end{tabular}


Tabel 3. Hasil Uji Hipotesis dan Chi-Square perubahan kecepatan di depan Faterna

\begin{tabular}{|c|l|c|c|c|c|}
\hline \multirow{2}{*}{$\begin{array}{c}\text { Jenis } \\
\text { Kendaraan }\end{array}$} & \multirow{2}{*}{ Lokasi } & \multicolumn{2}{|c|}{ Arah FE-Faperta } & \multicolumn{2}{c|}{ Arah Faperta-FE } \\
\cline { 3 - 6 } & & Keputusan & Keputusan & Keputusan & Keputusan \\
& & Uji z dan t & Uji chi-square & Uji z dan t & Uji chi-square \\
\hline \multirow{3}{*}{$\begin{array}{c}\text { Sepeda } \\
\text { Motor }\end{array}$} & Area 1-Area 2(Rumble strips) & $\mathrm{H}_{0}$ ditolak & $\mathrm{H}_{0}$ ditolak & $\mathrm{H}_{0}$ ditolak & $\mathrm{H}_{0}$ ditolak \\
& Area 2(Rumble strips)-Area 3 & $\mathrm{H}_{0}$ ditolak & $\mathrm{H}_{0}$ ditolak & $\mathrm{H}_{0}$ ditolak & $\mathrm{H}_{0}$ ditolak \\
& Area 3- Area 4 & $\mathrm{H}_{0}$ ditolak & $\mathrm{H}_{0}$ diterima & $\mathrm{H}_{0}$ ditolak & $\mathrm{H}_{0}$ ditolak \\
\hline \multirow{3}{*}{$\begin{array}{c}\text { Kendaraan } \\
\text { Ringan }\end{array}$} & Area 1-Area 2(Rumble strips) & $\mathrm{H}_{0}$ ditolak & $\mathrm{H}_{0}$ ditolak & $\mathrm{H}_{0}$ ditolak & $\mathrm{H}_{0}$ ditolak \\
& Area 2(Rumble strips)-Area 3 & $\mathrm{H}_{0}$ ditolak & $\mathrm{H}_{0}$ ditolak & $\mathrm{H}_{0}$ ditolak & $\mathrm{H}_{0}$ ditolak \\
& Area 3- Area 4 & $\mathrm{H}_{0}$ diterima & $\mathrm{H}_{0}$ diterima & $\mathrm{H}_{0}$ ditolak & $\mathrm{H}_{0}$ ditolak \\
\hline \multirow{3}{*}{$\begin{array}{c}\text { Angkutan } \\
\text { Umum }\end{array}$} & Area 1-Area 2(Rumble strips) & $\mathrm{H}_{0}$ ditolak & $\mathrm{H}_{0}$ ditolak & $\mathrm{H}_{0}$ ditolak & $\mathrm{H}_{0}$ ditolak \\
& Area 2(Rumble strips)-Area 3 & $\mathrm{H}_{0}$ ditolak & $\mathrm{H}_{0}$ ditolak & $\mathrm{H}_{0}$ ditolak & $\mathrm{H}_{0}$ ditolak \\
& Area 3- Area 4 & $\mathrm{H}_{0}$ diterima & $\mathrm{H}_{0}$ diterima & $\mathrm{H}_{0}$ diterima & $\mathrm{H}_{0}$ ditolak \\
\hline \multirow{3}{*}{ Bus } & Area 1-Area 2(Rumble strips) & $\mathrm{H}_{0}$ ditolak & $\mathrm{H}_{0}$ ditolak & $\mathrm{H}_{0}$ ditolak & $\mathrm{H}_{0}$ ditolak \\
& Area 2(Rumble strips)-Area 3 & $\mathrm{H}_{0}$ ditolak & $\mathrm{H}_{0}$ ditolak & $\mathrm{H}_{0}$ diterima & $\mathrm{H}_{0}$ diterima \\
& Area 3- Area 4 & $\mathrm{H}_{0}$ diterima & $\mathrm{H}_{0}$ diterima & $\mathrm{H}_{0}$ diterima & $\mathrm{H}_{0}$ diterima \\
\hline
\end{tabular}

Tabel 4. Hasil Uji Hipotesis dan Chi-Square perubahan kecepatan di depan Gedung Futsal

\begin{tabular}{|c|c|c|c|c|c|}
\hline \multirow{3}{*}{$\begin{array}{c}\text { Jenis } \\
\text { Kendaraan }\end{array}$} & \multirow{3}{*}{ Lokasi } & \multicolumn{2}{|c|}{ Arah Faperta-FMIPA } & \multicolumn{2}{|c|}{ Arah FMIPA-Faperta } \\
\hline & & Keputusan & Keputusan & Keputusan & Keputusan \\
\hline & & Uji $\mathrm{z}$ dan $\mathrm{t}$ & Uji chi-square & Uji z dan $\mathrm{t}$ & Uji chi-square \\
\hline \multirow{3}{*}{$\begin{array}{l}\text { Sepeda } \\
\text { Motor }\end{array}$} & Area 1-Area 2(Rumble strips) & $\mathrm{H}_{0}$ ditolak & $\mathrm{H}_{0}$ ditolak & $\mathrm{H}_{0}$ ditolak & $\mathrm{H}_{0}$ ditolak \\
\hline & Area 2(Rumble strips)-Area 3 & $\mathrm{H}_{0}$ ditolak & $\mathrm{H}_{0}$ ditolak & $\mathrm{H}_{0}$ ditolak & $\mathrm{H}_{0}$ ditolak \\
\hline & Area 3- Area 4 & $\mathrm{H}_{0}$ ditolak & $\mathrm{H}_{0}$ ditolak & $\mathrm{H}_{0}$ ditolak & $\mathrm{H}_{0}$ ditolak \\
\hline \multirow{3}{*}{$\begin{array}{c}\text { Kendaraan } \\
\text { Ringan }\end{array}$} & Area 1-Area 2(Rumble strips) & $\mathrm{H}_{0}$ ditolak & $\mathrm{H}_{0}$ ditolak & $\mathrm{H}_{0}$ ditolak & $\mathrm{H}_{0}$ ditolak \\
\hline & Area 2(Rumble strips)-Area 3 & $\mathrm{H}_{0}$ ditolak & $\mathrm{H}_{0}$ ditolak & $\mathrm{H}_{0}$ ditolak & $\mathrm{H}_{0}$ ditolak \\
\hline & Area 3- Area 4 & $\mathrm{H}_{0}$ diterima & $\mathrm{H}_{0}$ diterima & $\mathrm{H}_{0}$ ditolak & $\mathrm{H}_{0}$ ditolak \\
\hline \multirow{3}{*}{$\begin{array}{l}\text { Angkutan } \\
\text { Umum }\end{array}$} & Area 1-Area 2(Rumble strips) & $\mathrm{H}_{0}$ ditolak & $\mathrm{H}_{0}$ ditolak & $\mathrm{H}_{0}$ ditolak & $\mathrm{H}_{0}$ ditolak \\
\hline & Area 2(Rumble strips)-Area 3 & $\mathrm{H}_{0}$ ditolak & $\mathrm{H}_{0}$ ditolak & $\mathrm{H}_{0}$ ditolak & $\mathrm{H}_{0}$ ditolak \\
\hline & Area 3- Area 4 & $\mathrm{H}_{0}$ ditolak & $\mathrm{H}_{0}$ diterima & $\mathrm{H}_{0}$ ditolak & $\mathrm{H}_{0}$ diterima \\
\hline \multirow{3}{*}{ Bus } & Area 1-Area 2(Rumble strips) & $\mathrm{H}_{0}$ ditolak & $\mathrm{H}_{0}$ ditolak & $\mathrm{H}_{0}$ ditolak & $\mathrm{H}_{0}$ ditolak \\
\hline & Area 2(Rumble strips)-Area 3 & $\mathrm{H}_{0}$ ditolak & $\mathrm{H}_{0}$ ditolak & $\mathrm{H}_{0}$ ditolak & $\mathrm{H}_{0}$ diterima \\
\hline & Area 3- Area 4 & $\mathrm{H}_{0}$ diterima & $\mathrm{H}_{0}$ diterima & $\mathrm{H}_{0}$ ditolak & $\mathrm{H}_{0}$ diterima \\
\hline
\end{tabular}


Tabel 5. Hasil Uji Hipotesis dan Chi-Square perubahan kecepatan di depan Kopma

\begin{tabular}{|c|l|c|c|c|c|}
\hline \multirow{2}{*}{$\begin{array}{c}\text { Jenis } \\
\text { Kendaraan }\end{array}$} & \multicolumn{2}{|c|}{ Lokasi } & \multicolumn{2}{|c|}{ Arah Faperta-FMIPA } & \multicolumn{2}{c|}{ Arah FMIPA-Faperta } \\
\cline { 3 - 6 } & & Keputusan & Keputusan & Keputusan & Keputusan \\
\hline \multirow{2}{*}{$\begin{array}{c}\text { Sepeda } \\
\text { Motor }\end{array}$} & Area 1-Area 2(Rumble strips) & $\mathrm{H}_{0}$ ditolak & $\mathrm{H}_{0}$ ditolak & $\mathrm{H}_{0}$ ditolak & $\mathrm{H}_{0}$ ditolak \\
& Area 2(Rumble strips)-Area 3 & $\mathrm{H}_{0}$ ditolak & $\mathrm{H}_{0}$ ditolak & $\mathrm{H}_{0}$ ditolak & $\mathrm{H}_{0}$ ditolak \\
& Area 3- Area 4 & $\mathrm{H}_{0}$ ditolak & $\mathrm{H}_{0}$ ditolak & $\mathrm{H}_{0}$ ditolak & $\mathrm{H}_{0}$ ditolak \\
\hline \multirow{3}{*}{$\begin{array}{c}\text { Kendaraan } \\
\text { Ringan }\end{array}$} & Area 1-Area 2(Rumble strips) & $\mathrm{H}_{0}$ ditolak & $\mathrm{H}_{0}$ ditolak & $\mathrm{H}_{0}$ ditolak & $\mathrm{H}_{0}$ ditolak \\
& Area 2(Rumble strips)-Area 3 & $\mathrm{H}_{0}$ ditolak & $\mathrm{H}_{0}$ ditolak & $\mathrm{H}_{0}$ ditolak & $\mathrm{H}_{0}$ ditolak \\
& Area 3- Area 4 & $\mathrm{H}_{0}$ ditolak & $\mathrm{H}_{0}$ ditolak & $\mathrm{H}_{0}$ ditolak & $\mathrm{H}_{0}$ ditolak \\
\hline \multirow{3}{*}{$\begin{array}{c}\text { Angkutan } \\
\text { Umum }\end{array}$} & Area 1-Area 2(Rumble strips) & $\mathrm{H}_{0}$ ditolak & $\mathrm{H}_{0}$ ditolak & $\mathrm{H}_{0}$ ditolak & $\mathrm{H}_{0}$ ditolak \\
& Area 2(Rumble strips)-Area 3 & $\mathrm{H}_{0}$ ditolak & $\mathrm{H}_{0}$ ditolak & $\mathrm{H}_{0}$ ditolak & $\mathrm{H}_{0}$ ditolak \\
& Area 3- Area 4 & $\mathrm{H}_{0}$ ditolak & $\mathrm{H}_{0}$ ditolak & $\mathrm{H}_{0}$ diterima & $\mathrm{H}_{0}$ diterima \\
\hline \multirow{2}{*}{ Bus } & Area 1-Area 2(Rumble strips) & $\mathrm{H}_{0}$ ditolak & $\mathrm{H}_{0}$ ditolak & $\mathrm{H}_{0}$ ditolak & $\mathrm{H}_{0}$ ditolak \\
& Area 2(Rumble strips)-Area 3 & $\mathrm{H}_{0}$ ditolak & $\mathrm{H}_{0}$ ditolak & $\mathrm{H}_{0}$ ditolak & $\mathrm{H}_{0}$ diterima \\
& Area 3- Area 4 & $\mathrm{H}_{0}$ ditolak & $\mathrm{H}_{0}$ ditolak & $\mathrm{H}_{0}$ ditolak & $\mathrm{H}_{0}$ diterima \\
\hline
\end{tabular}

Tabel 6. Hasil Uji Hipotesis dan Chi-Square perubahan kecepatan di depan Kopma

\begin{tabular}{|c|c|c|c|}
\hline Jenis Kendaraan & Lokasi & $\begin{array}{c}\text { Keputusan Hasil } \\
\text { Uji z dan t }\end{array}$ & $\begin{array}{c}\text { Keputusan } \\
\text { Hasil } \\
\text { Uji Chi } \\
\text { Square }\end{array}$ \\
\hline \multirow{3}{*}{ Sepeda Motor } & Area 1-Area 2 (Rumble Strips) & $\mathrm{H}_{0}$ ditolak & $\mathrm{H}_{0}$ ditolak \\
\hline & Area 2(Rumble Strips)-Area 3 & $\mathrm{H}_{0}$ ditolak & $\mathrm{H}_{0}$ ditolak \\
\hline & Area 3-Area 4 & $\mathrm{H}_{0}$ ditolak & $\mathrm{H}_{0}$ ditolak \\
\hline \multirow{3}{*}{ Kendaraan Ringan } & Area 1-Area 2 (Rumble Strips) & $\mathrm{H}_{0}$ ditolak & $\mathrm{H}_{0}$ ditolak \\
\hline & Area 2(Rumble Strips)-Area 3 & $\mathrm{H}_{0}$ ditolak & $\mathrm{H}_{0}$ ditolak \\
\hline & Area 3-Area 4 & $\mathrm{H}_{0}$ ditolak & $\mathrm{H}_{0}$ ditolak \\
\hline \multirow{3}{*}{ Angkot } & Area 1-Area 2 (Rumble Strips) & $\mathrm{H}_{0}$ ditolak & $\mathrm{H}_{0}$ ditolak \\
\hline & Area 2(Rumble Strips)-Area 3 & $\mathrm{H}_{0}$ ditolak & $\mathrm{H}_{0}$ ditolak \\
\hline & Area 3-Area 4 & $\mathrm{H}_{0}$ ditolak & $\mathrm{H}_{0}$ ditolak \\
\hline \multirow{3}{*}{ Bus } & Area 1-Area 2 (Rumble Strips) & $\mathrm{H}_{0}$ ditolak & $\mathrm{H}_{0}$ ditolak \\
\hline & Area 2(Rumble Strips)-Area 3 & $\mathrm{H}_{0}$ ditolak & $\mathrm{H}_{0}$ ditolak \\
\hline & Area 3-Area 4 & $\mathrm{H}_{0}$ ditolak & $\mathrm{H}_{0}$ diterima \\
\hline
\end{tabular}

Berdasarkan hasil uji z dan $\mathrm{t}$ dengan uji chi- square, lokasi penelitiaan rumble strips didepan FE, Faterna dan gedung futsal berdasarkan hasil uji z dan $\mathrm{t}$ seta uji Chi-square, perubahan kecepatan rata-rata kendaraan yang tidak dipengaruhi rumble strips terjadi ketika kendaraan melewati area3area 4, ini terjadi pada semua jenis kendaraan, baik itu untuk kendaraan menuju arah naik (PKMfaterna, FE-Faperta dan Faperta-FMIPA) maupun arah turun (Faperta-PKM, Faperta-FE, FMIPAFaperta). Lokasi di depan Kopma untuk kecepatan rata-rata kendaraan arah naik (Faperta-FMIPA) rata-rata perubahan kecepatan kendaraan dipengaruhi oleh rumble strips, sedangkan kecepatan ratarata kendaraan untuk arah turun (FMIPA-Faperta) perubahan kecepatan rata-rata kendaraan yang tidak dipengaruhi rumble strips terjadi ketika kendaraan melewati area3-area4 untuk jenis kendaraan angkot, sedangkan untuk bus ketika melewati area2-3 dan area3-area4. Sedangkan untuk 
lokasi di depan PKM rata-rata perubahan kecepatan kendaraan dipengaruhi oleh rumble strips kecuali kecepatan rata-rata bus ketika melewati area3-area4.

\section{KESIMPULAN}

Berdasarkan hasil penelitian dan analisa yang dilakukan dapat diambil kesimpulan sebagai berikut:

a. Kecepatan rata-rata kendaraan di kawasan kampus UNAND Limau Manis

\begin{tabular}{|l|c|c|c|c|}
\hline \multirow{2}{*}{ Jenis Kendaraan dan Arah Lokasi Penelitian } & \multicolumn{4}{|c|}{ Kecepatan Rata-rata Kendaraan (Km/Jam) } \\
\cline { 2 - 5 } & Area 1 & Area 2 (Rumble Strips) & Area 3 & Area 4 \\
\hline Sepeda motor (arah Naik) & 36.5 & 33.7 & 37.0 & 36.8 \\
Sepeda Motor (arah Turun) & 35.1 & 31.1 & 34.4 & 35.8 \\
Kendaraan Ringan (arah naik) & 37.9 & 34.9 & 38.2 & 38.3 \\
Kendaraan Ringan (arah Turun) & 35.9 & 32.2 & 35.1 & 36.4 \\
Angkot (arah Naik) & 29.8 & 27.2 & 30.6 & 33.2 \\
Angkot (arah Turun) & 29.3 & 26.1 & 29.4 & 30.0 \\
Bus (arah Naik) & 37.0 & 33.5 & 37.1 & 37.2 \\
Bus (arah Turun) & 34.8 & 30.9 & 34.5 & 36.3 \\
\hline
\end{tabular}

b. Persentase penurunan kecepatan rata-rata kendaraan di kawasan kampus UNAND Limau Manis ketika melewati rumble strips (area 2) dibandingkan dengan sebelum melewati rumble strips (area 1) yaitu 7,8 \% untuk sepeda motor (arah naik), 11,4\% untuk sepeda motor (arah turun), 8,1\% untuk kendaraan ringan (arah naik), 10,3\% untuk kendaraan ringan (arah turun), 8,5\% untuk angkot (arah naik), 10,8\% untuk angkot (arah turun), 9,5\% untuk bus (arah naik) dan $11,3 \%$ untuk bus (arah turun)

c. Berdasarkan pengamatan dari 5 lokasi penelitian rumble strips, lokasi dibagi menjadi 3 segmen yang berbeda yaitu :

a) Lokasi penelitiaan rumble strips didepan FE, didepan Faterna dan di depan Gedung futsal dianggap mempunyai karakteristik yang hampir sama karena lokasi yang saling berdekatan, selain itu persamaan karakteristik ini bisa dilihat dari hasil uji z dan t serta uji chi-square menunjukan bahwa perubahan kecepatan kendaraan tidak dipengaruhi oleh rumble strips ketika melewati area 3 menuju area 4 untuk kendaraan sepeda motor, kendaraan ringan, angkot dan bus

b) Lokasi penelitian rumble strips di depan Kopma dianggap sedikit berbeda lokasi penelitian di depan FE, di depan Faterna dan di depan Gedung Futsal, hasil uji z dan t seta uji chi-square khususnya arah FMIPA-FT yg menunjukkan hasil perubahan kecepatan kendaraan yang tidak dipengaruhi oleh rumble strips di area 3 menuju area 4 hanya untuk kendaraan angkot dan bus.

c) Lokasi di depan PKM dianggap cukup berbeda dengan 4 lokasi penelitian rumble strips sebelumnya karena rumble strips ditempatkan hanya pada arah turun saja kemudian dilokasi penelitian ini juga terdapat beberapa garis penggaduh sebelum rumble strips dan ini sangat berpengaruh terhadap hasil uji $\mathrm{z}$ dan $\mathrm{t}$ yg menunjukkan semua perubahan kecepatan kendaraan dipengaruhi rumble strips, sedangkan berdasarkan chi-square khususnya untuk bus ketika melewati area 3 menuju area 4 perubahan kecepatan tidak di pengaruhi oleh rumble strips. 


\section{DAFTAR KEPUSTAKAAN}

Departemen Perhubungan. 1994, Keputusan Menteri Perhubungan Nomor 3 Tahun 1994 Tentang Alat Pengendali dan Pengaman Pemakai Jalan, Jakarta.

Julianto, E, N. 2010, Hubungan antara Kecepatan, Volume dan Kepadatan Lalu lintas Ruas Jalan Siliwangi Semarang, Jurnal Teknik Sipil \& Perencanaan, No 2 Volume 12-juli 2010, diakses tanggal 13 April 2013, journal.unnes.ac.id/nju/index.php/jtsp/.../1453

Meydita, $N$ dan Kusumawati, A. 2012, Pengaruh Pita Penggaduh Melintang terhadap Kecepatan Kendaraan Ringan dan Angka Kecelakaan di Tol Cipularang, Jurnal Transportasi Volume 12 No 3 Desember 2012: $165-174$

Michael J. C, Jame W. S and Jenny L. G. 1993, Rumble Strips and Pedestrian Savety, ITE Journal.

Tamin O. Z. 2008. Perencanaan Pemodelan dan Rekayasa Transportasi, Penerbit ITB, Bandung.

Widya G.A, 2007. Penyusunan Sistem Manajemen dan Pedoman Keselamatan Jalan dalam Kegiatan Pembangunan Jalan. Departemen Pekerjaan Umum

Sudjana. 1992, Metoda Statistik, Edisi ke-5, Penerbit Tarsito, Bandung 